\title{
Density of bone formed after sinus augmentation with Nanobone versus that of bone formed after sinus lift with tenting technique : Preliminary study
}

Original

\author{
Khaled Mohamed Shawky, Mohammed Farid Shehab, Fahmy Abdel Aal Hassanein
}

Department of Oral and Maxillofacial Surgery, Faculty of Oral and Dental Medicine, Cairo University, Cairo, Egypt

\begin{abstract}
Aim: Comparing the density of bone formed after sinus lifting and augmentation with Nanobone graft to that of the newly formed bone after non-augmented sinus lifting with tenting technique.

Materials and Methods: A total of 12 maxillary sinuses requiring lifting and augmentation procedures were divided into two groups: Group 1: comprised six patients in which grafted maxillary sinus lifting with Nanobone graft procedures were performed, Group 2: comprised six patients in which non-grafted maxillary sinus lifting procedures were performed. Simultaneous implant placement was performed in both groups. Implants were left for six months after placement in bone to ensure complete osseointegration before loading.

Results: Immediately post-operative, after 6 months and after 9 months, the mean bone density of grafted group showed statistically significantly higher value than non grafted group. This is due to the continued bone formation in the grafted group.

Conclusion: There is significant increase in density of bone formed after augmented sinus lifting with Nanobone more than that of newly formed bone after non-augmented sinus lifting in the first nine months after the maxillary sinus lifting operation with simultaneous implants placement.
\end{abstract}

Key Words: Bone density, implants, Nano-bone, tenting technique.

Received: 05 January 2019, Accepted: 23 April 2019

Corresponding Author: Khaled M. Shawky, Department of Oral and Maxillofacial Surgery, Faculty of Oral and Dental Medicine, Cairo University, Tel.: 00201227542990, E-mail: khaledshawky8@hotmail.com

ISSN: 2090-097X, January 2019, Vol. 10, No. 1

\section{INTRODUCTION}

Numerous techniques have evolved to overcome the problem of reduced bone volume available in the posterior atrophic maxilla. The lateral window approach technique (Fig. 1)by the aid of Dentium Advanced Sinus Kit (DASK) (Fig. 2) is used for augmentation of the maxillary sinus with bone graft after sinus floor elevation and simultaneous creation of a new compartment between alveolar bone and floor of maxillary sinus. This new compartment may be filled with either autogenous graft, allografts, xenografts, or combination of them to maintain space for new bone formation $^{[1-4]}$.

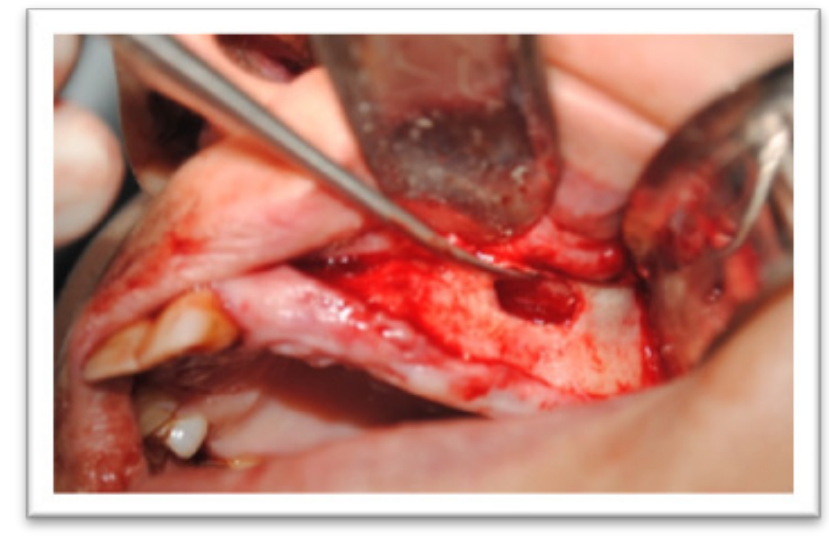

Fig. 1: Lateral window technique 


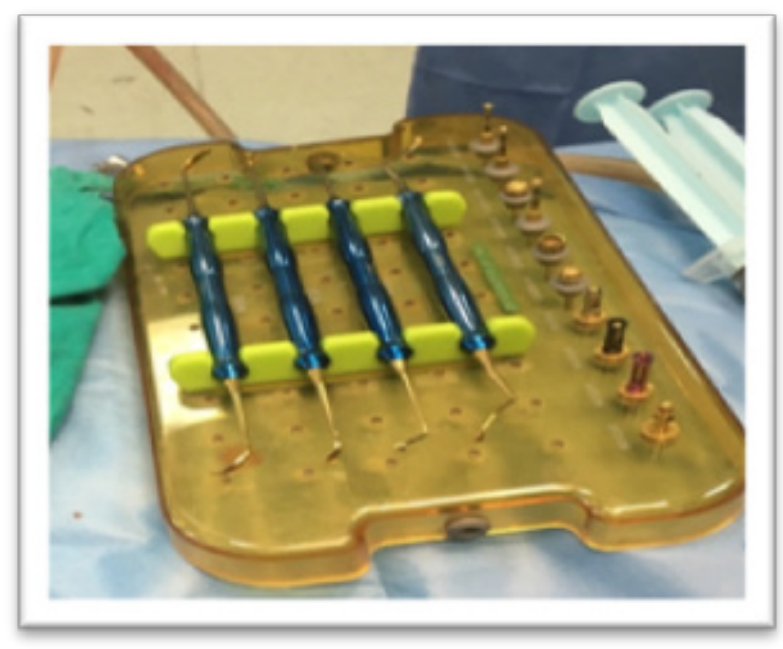

Fig. 2: Dentium Advanced Sinus Kit

Nanobone is a recently developed and approved granular material consisting of nanocrystalline HA embedded in a silica gel matrix, which offers several of the advantages of nanostructural biomaterials. Because of the open $\mathrm{SiOH}$ or $\mathrm{SiO}$ groups of polysilicic acid, the internal surface of this material is extremely large (about $84 \mathrm{~m} 2 / \mathrm{g}$ ). The interconnecting pores in the silica gel have sizes ranging from 10 to $20 \mathrm{~nm}$, leading to material porosity of about $60 \%$. The surface of the granules is very rough, thus creating an inter-connecting porous structure ranging from micrometer to millimeter dimensions. However, Nanobone has a high breaking strength of about $40 \mathrm{Mpa}^{[-9]}$.

Bone formation occurs when sinus floor elevation is performed using a trans-alveolar osteotomy technique without placing any graft material in the maxillary sinus. In 1993, Boyne presented experimental results from a study in which implants were left without grafts to protrude 5 $\mathrm{mm}$ into the sinus floor and experienced bone formation. In 2004, Lundgren et al. showed evidence of bone formation around all installed implants after sinus lifting without grafting with bone, the blood clot was allowed to form in the sub-antral membrane space to act as a scaffold for new bone formation. The installed implants act as spacemaintaining device under the lifted membrane ${ }^{[10,12]}$.

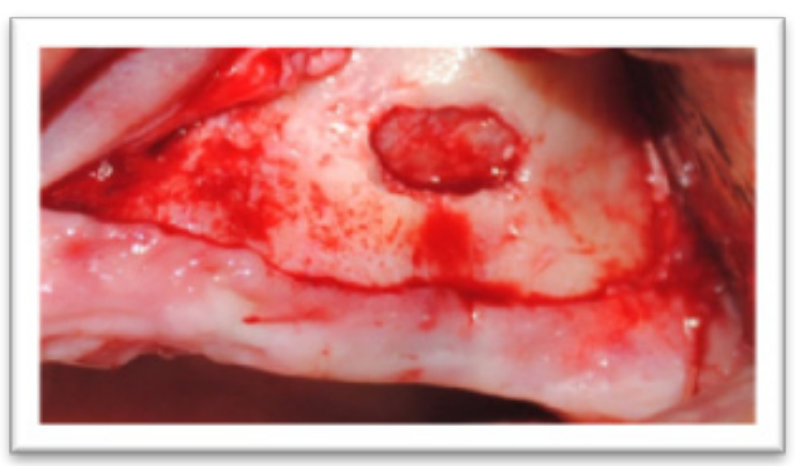

\section{MATERIALS AND METHODS}

A total of 12 maxillary sinuses requiring lifting and augmentation procedures were divided into two groups:

- Group 1: comprised six patients in which grafted maxillary sinus lifting with Nanobone graft procedures were performed.

- Group 2: comprised six patients in which non-grafted maxillary sinus lifting procedures were performed.

- Data have been collected from twelve subjects, aged 36-56 years with mean age of 41.4 years and male: female ratio of five: seven

- Simultaneous implant placement was performed in both groups. Implants were left for six months after placement in bone to ensure complete osseointegration before loading.

- The subantral bone height should be at least $5 \mathrm{~mm}$ from crest of the edentulous ridge to the base of the sinus membrane.

- Number of implants to be inserted in each edentulous side are from 2 to 3 implants to restore the area from canine distally.

\section{Surgical Procedures:}

1. Surgeries were operated under general anesthesia

2. Incision was made using a Bard Parker blade number 15 palatal to the crest of the ridge, extending distally $2 \mathrm{~cm}$ to the osteotomy site and continues anteriorly till the distal of the canine of the same side of the edentulous ridge.

3. Releasing mesiovertical incision was made at the anterior end of the incision for better visualization of the surgical field. A large bony window was made at the lateral sinus wall using dash bur and large round smooth bur under copious external irrigation

4. The osteotomy at the inferior aspect of the window was made at or as close to the level of superior aspect of residual alveolar bone height

5. Bony window made with dimensions of about $2 \mathrm{~cm}$ anteroposteriorly and $1.5 \mathrm{~cm}$ vertical cuts (Fig. 3)

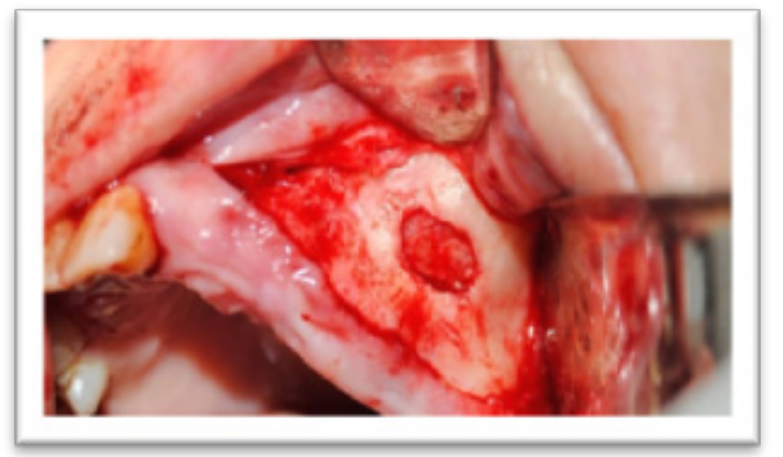

Fig. 3: Clinical photographs showing flap reflection and creation of a bony window in the edentulous maxillary region opposite to the maxillary sinus (the sinus membrane can be seen through the bony window) 
6. The sinus membrane was detached from the margins of bony window using DASK.

7. Once the outline was completely detached, the sinus elevator was used to push the sinus membrane inside gently and dissect from the sinus floor so the membrane was completely free from inferior and medial aspects (Fig. 4)
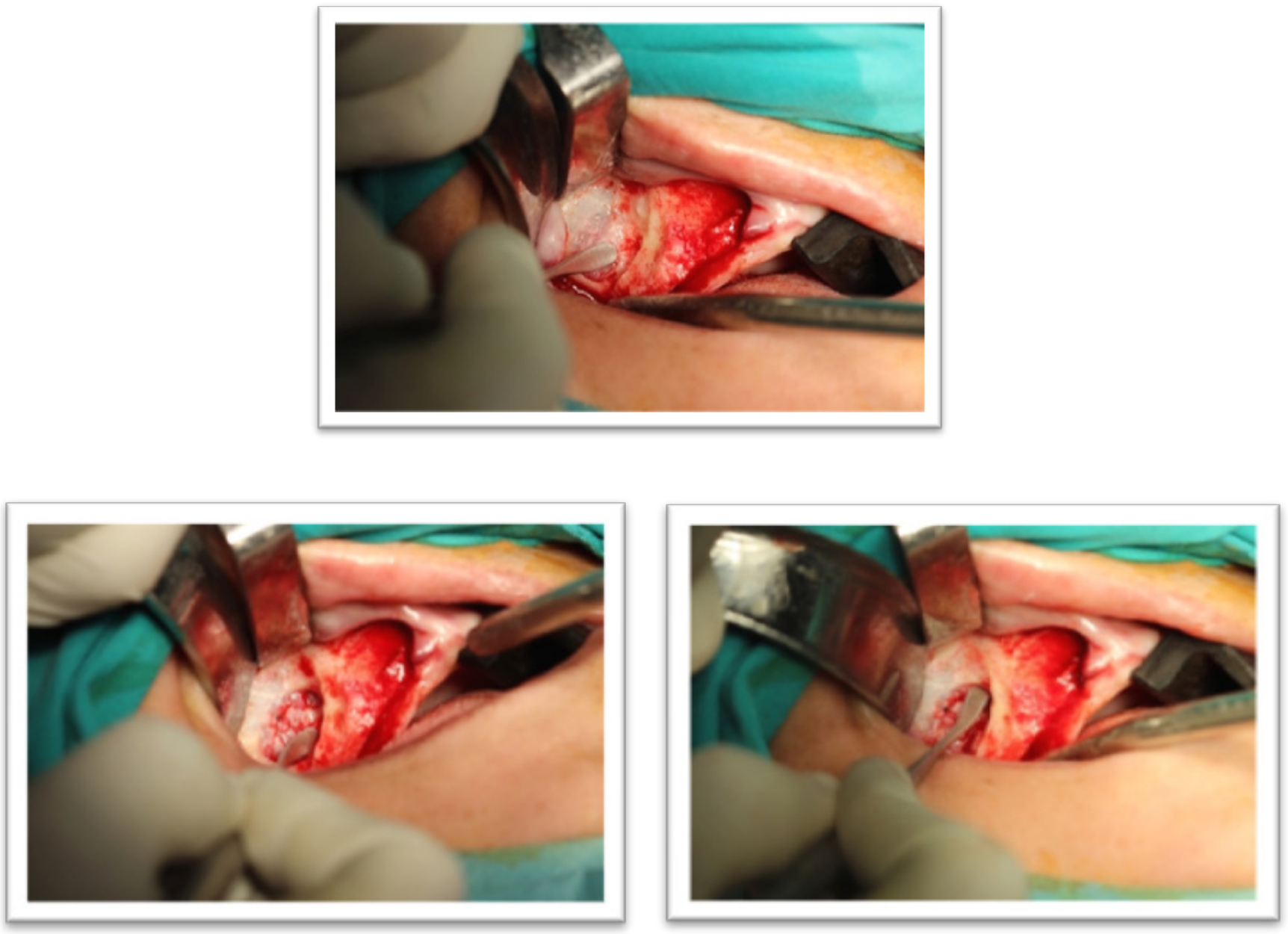

Fig. 4: The use of sinus elevator to push the sinus membrane inside gently and dissect from the sinus floor

8. The implant site was marked using a surgical template and osteotomy was performed using pilot drill with copious amount of coolant to guide the rest of the drills in correct positions and angulations.

9. The surgical stent was removed then drills were used in a sequential manner till the required diameter for the fixture was reached.

10. Patients were divided into two groups: For group 1:
Nanocrystalline hydroxyapatite (ArtossNanobone) was prepared by mixing the graft granules with saline.The graft material was placed at the superior aspect of the sinus and against the medial aspect of the grafted compartment created in the sinus cavity (Fig. 5). [or group 2, no graft was placed.

11. For both groups, the implants were inserted into the prepared osteotomy sites (Fig. 6). 
A

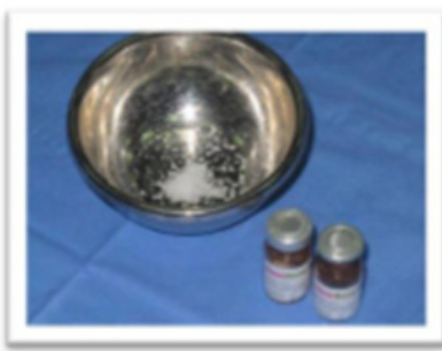

B
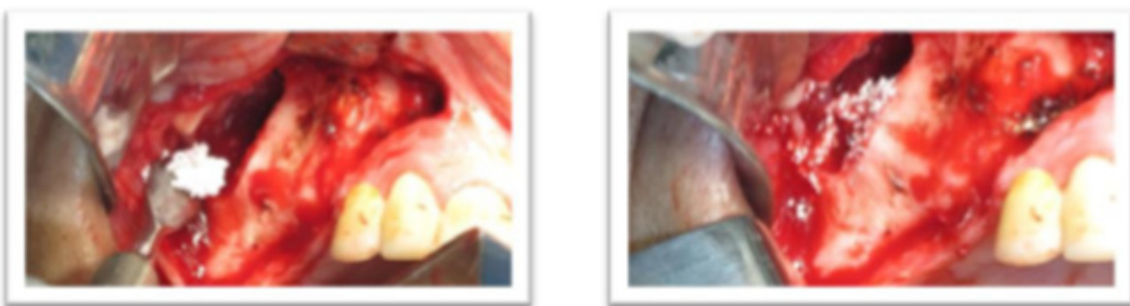

C
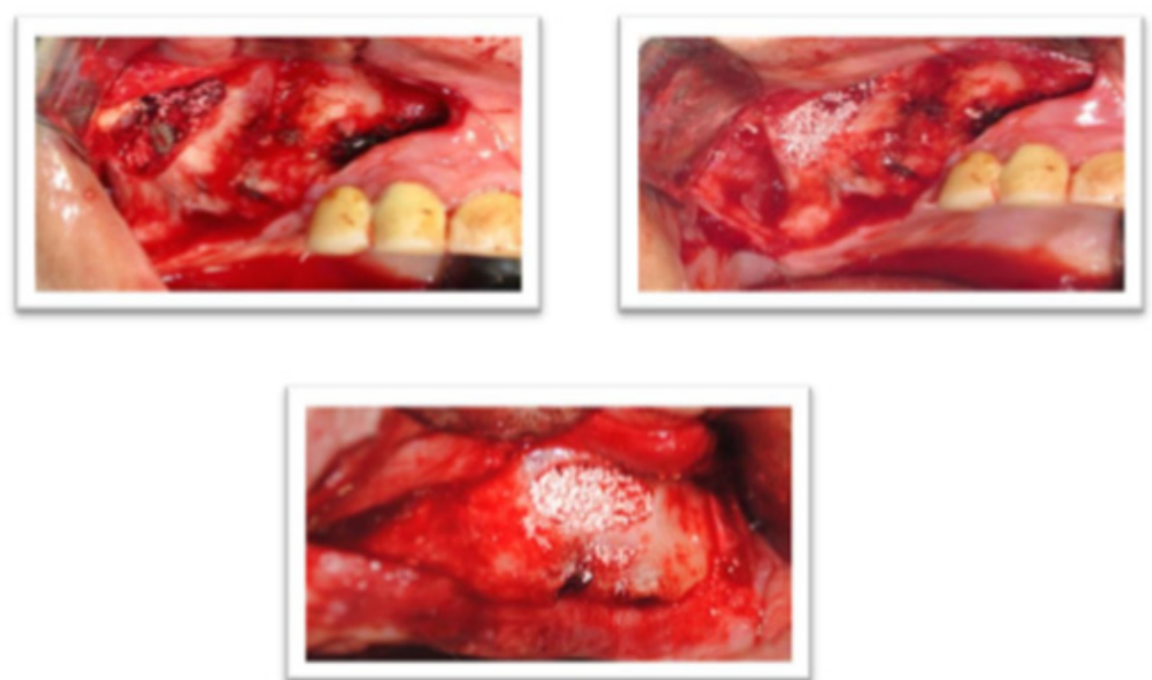

Fig. 5: Clinical photographs showing condensation of the Nanobone graft before (B) and after (C) implants placement below the elevated maxillary sinus

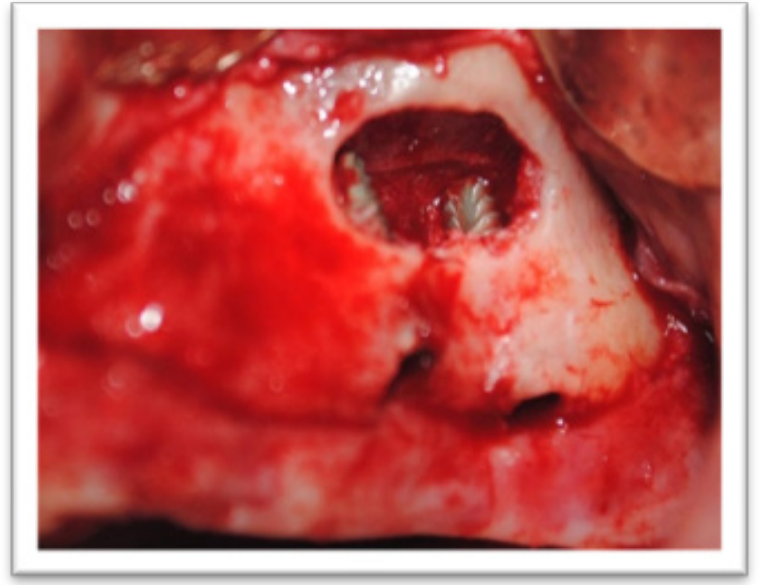

Fig. 6: Clinical photographs showing implants placed under the elevated maxillary sinus
12. The sinus freer was held in place carrying the sinus membrane upwards to avoid any unvisualized tension from the implant on the sinus membrane.

13. For group 1, the rest of the graft material was condensed around the implant to fill the defect.

14. The cover screws of the implants were placed. The flap was then repositioned and the edges were sutured in an interrupted mattress suture using resorbable suture material.

15. Inserted implants were left for six months in bone to ensure complete osseointegration before loading.

\section{Radiographic assessment:}

Postoperative panoramic radiographs and computerized tomography (CT) scan of $0.6 \mathrm{~mm}$ cuts axial, reformatted sagittal and coronal cuts with two $\mathrm{mm}$ interval were 
performed two weeks after the surgery and other scans were performed later after six and nine months.

\section{CT analysis:}

Bone height and density were assessed in comparable standardized sagittal cuts from CT scans performed two weeks after surgery, six months after surgery and nine months after the surgery (three months after implants loading). Analysis of bone height using linear measurements extended from the line of demarcation visible the native bone and grafted bone or newly formed bone to the end of the graft while being perpendicular to the alveolar ridge and an average mean value in millimeters was calculated. Analysis of bone density by taking five random readings for densities using rectangular shapes with specified area of the native bone and newly formed bone of both groups then an average mean value was calculated in Hounsfield units (HU) (Figure 7).

\section{Statistical analysis:}

Comparisons between the changes in bone density within the members of each group separately and between the two groups in term of mean and standard deviation were performed. Paired t-test was used to study the changes by time in each group. Student's t-test was used to study the changes in bone density between the two groups. The significance level was set as $P<0.05$. Statistical analysis and figures were performed with Graph Pad Prism 5 for windows.

\section{RESULTS}

\section{Clinical Results:}

\section{Pre-operative Clinical Data:}

All the patients received detailed clinical examination: no abnormalities in soft or hard tissue had been recorded. All the patients had a health overlying keratinized mucosa. All patients had been examined radiographically through ConebeamCT. One patient had a maxillary sinus septum that was apparent in the panoramic view in the molar region.

\section{Operative Clinical Data}

Patients had been operated under general anaesthesia. All the patients underwent maxillary sins lift using lateral antrostomy approach. No complication had been recorded during the operation.

\section{Post-Operative Follow-Up Clinical Data}

All the patients had been examined periodically during the follow period up to nine months. All the patients had completed the scheduled follow up. Swelling was observed in all patients during the first week post operatively and was completely resolved by the seventh- nineth post-operative day. All the patients had removed the sutures after tenfourteen days. Healing was uneventful in all patients.

\section{Bone density}

Immediately post-operative, after 6 months and after 9 months, the mean bone density of grafted group showed statistically significantly higher value than non grafted group as showed in Fig. 8 and Table 1. This is due to the continued bone formation in the grafted group (Table 2, 3)

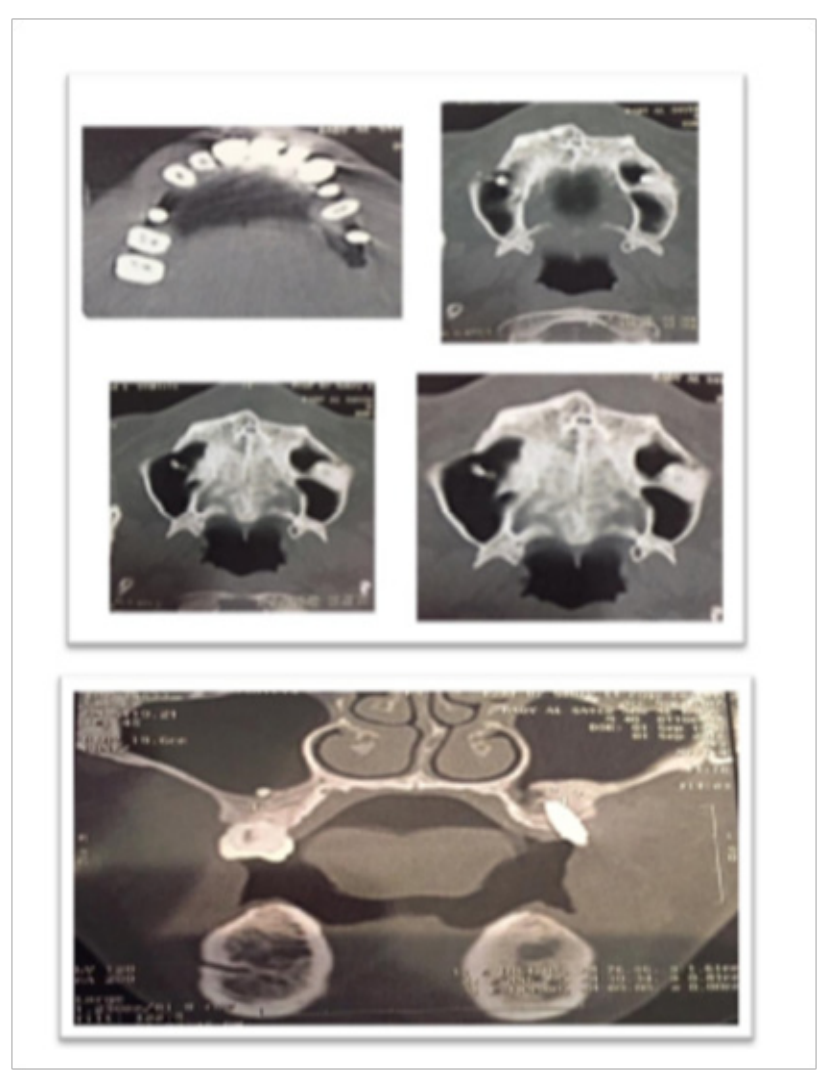

Fig. 7: computerized tomography scans of a case that have undergone grafted sinus lifting on the left side and non-grafted sinus lifting on the right side showing CT number in HU.

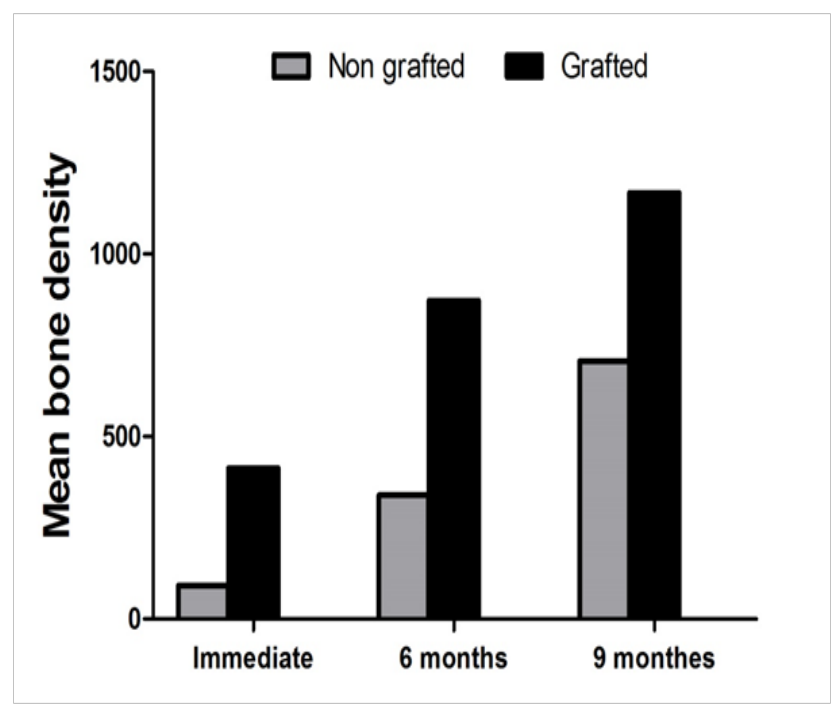

Fig. 8: Bar chart comparing the change in bone density between the two groups. 
Table 1: Mean, standard deviation (SD) values and results of student's t-test for comparison between bone density of the two groups

\begin{tabular}{|c|c|c|c|c|c|}
\hline \multirow{2}{*}{ Period Group } & \multicolumn{2}{|c|}{ Non-grafted } & \multicolumn{2}{|c|}{ Grafted } & \multirow{2}{*}{$P$-value } \\
\hline & Mean & SD & Mean & SD & \\
\hline Immediate & 92.08 & 221.6 & 413.7 & 32.73 & $0.0056^{* *}$ \\
\hline 6 months & 339.9 & 76.64 & 872.5 & 265.9 & $0.0008 * * *$ \\
\hline 9 months & 706.0 & 125.7 & 1168 & 193.6 & $0.0006 * * *$ \\
\hline
\end{tabular}

**: Significant at $P<0.005 ; * * *$ : significant at $P<0.0005$

Table 2: Bone density in patients undergone grafted sinus lift.

\begin{tabular}{|c|c|c|c|c|c|c|}
\hline Case no & 1 & 2 & 3 & 4 & 5 & 6 \\
\hline Diabetes & Non & Non & Non & $\begin{array}{l}\text { Controlled } \\
\text { Diabetic }\end{array}$ & Non & Non \\
\hline Smoking & Non & Non & Non & Non & Non & Non \\
\hline Bone size & $\begin{array}{l}5.8 \mathrm{~mm}^{*} \\
6.04 \mathrm{~mm}\end{array}$ & $\begin{array}{l}7 \mathrm{~mm} * \\
5.8 \mathrm{~mm}\end{array}$ & $\begin{array}{c}5.45 \mathrm{~mm}^{*} \\
5.82 \mathrm{~mm}\end{array}$ & $\begin{array}{c}5.03 \mathrm{~mm} * \\
5.5 \mathrm{~mm}\end{array}$ & $5.7 \mathrm{~mm} * 5.2 \mathrm{~mm}$ & $6.8 \mathrm{~mm} * 6.02 \mathrm{~mm}$ \\
\hline Grafted or non grafted & Grafted & Grafted & Grafted & Grafted & Grafted & Grafted \\
\hline Tooth no. & $\begin{array}{l}\text { Upper } \\
\text { Left } 7\end{array}$ & $\begin{array}{l}\text { Upper } \\
\text { right } 7\end{array}$ & Upper left 6 & $\begin{array}{l}\text { Upper } \\
\text { right } 6\end{array}$ & Upper left first premolar & $\begin{array}{l}\text { Upper right first } \\
\text { premolar }\end{array}$ \\
\hline Age & 51 years & 56 years & 42 years & 49 years & 46 years & 37 years \\
\hline Gender & Female & Female & male & female & Female & Male \\
\hline Implant distribution & $\begin{array}{l}1 \text { at anterior } \\
2 \text { at molar } \\
\text { region }\end{array}$ & $\begin{array}{l}2 \text { at molar } \\
\text { region }\end{array}$ & $\begin{array}{l}1 \text { at premolar } \\
1 \text { at molar }\end{array}$ & $\begin{array}{l}1 \text { at molar } \\
1 \text { at canine }\end{array}$ & $\begin{array}{c}2 \text { implants : } 1 \text { at left } \\
\text { premolar region and } \\
1 \text { at molar region }\end{array}$ & $\begin{array}{l}2 \text { implants : } 1 \text { at } \\
\text { premolar region and } \\
1 \text { at molar region }\end{array}$ \\
\hline $\begin{array}{l}\text { HU after } 2 \text { weeks } \\
\text { post-operative }\end{array}$ & 173.58 & 147.48 & 450.23 & 453.96 & 733.10 & 523.64 \\
\hline $\begin{array}{l}\text { HU after six months } \\
\text { post-operative }\end{array}$ & 612.56 & 532.86 & 896.75 & 924.28 & 1257.56 & 1010.87 \\
\hline $\begin{array}{l}\text { HU after nine months } \\
\text { post-operative }\end{array}$ & 980.23 & 1181.23 & 1010.64 & 1054.18 & 1478.89 & 1300.887 \\
\hline
\end{tabular}

Table 3: bone density in patients undergone non grafted sinus lift.

\begin{tabular}{|c|c|c|c|c|c|c|}
\hline Case no & 1 & 2 & 3 & 4 & 5 & 6 \\
\hline Diabetes & Non & Non & Non & Non & Non & Non \\
\hline Smoking & Non & Non & Non & Non & Non & Non \\
\hline Bone size & $\begin{array}{c}5.04 \mathrm{~mm} * \\
7.02 \mathrm{~mm}\end{array}$ & $\begin{array}{l}6.02 \mathrm{~mm} \\
* 6.3 \mathrm{~mm}\end{array}$ & $6 \mathrm{~mm} * 5.7 \mathrm{~mm}$ & $6 \mathrm{~mm} * 5 \mathrm{~mm}$ & $6 \mathrm{~mm} * 7 \mathrm{~mm}$ & $6 \mathrm{~mm} * 7 \mathrm{~mm}$ \\
\hline Grafted or non grafted & Non-grafted & $\begin{array}{l}\text { Non- } \\
\text { grafted }\end{array}$ & Non-grafted & Non-grafted & Non-grafted & Non-grafted \\
\hline Tooth no. & Upper right 7 & $\begin{array}{l}\text { Upper } \\
\text { right } 7\end{array}$ & $\begin{array}{l}\text { Upper right } \\
\text { first molar }\end{array}$ & $\begin{array}{c}\text { Upper left } \\
\text { second premolar }\end{array}$ & $\begin{array}{l}\text { Upper right } \\
\text { first molar }\end{array}$ & $\begin{array}{l}\text { Upper left } \\
\text { first molar }\end{array}$ \\
\hline Age & 47 years & 42 years & 46 years & 37 years & 36 years & 36 years \\
\hline Gender & Male & Male & Female & Male & Female & Female \\
\hline Implant distribution & $\begin{array}{l}1 \text { at molar } \\
\text { region }\end{array}$ & $\begin{array}{l}1 \text { at molar } \\
\text { region }\end{array}$ & $\begin{array}{l}2 \text { implants : } 1 \\
\text { at right molar } \\
\text { region and } 1 \text { at } \\
\text { premolar region }\end{array}$ & $\begin{array}{l}2 \text { implants: } 1 \\
\text { at premolar } \\
\text { region and } 1 \text { at } \\
\text { molar region }\end{array}$ & 1 implant & $\begin{array}{l}2 \text { implants at } \\
\text { molar region }\end{array}$ \\
\hline $\begin{array}{l}\text { HU after } 2 \text { weeks } \\
\text { post-operative }\end{array}$ & 73.85 & 65.38 & 55.7 & 134.78 & 125.87 & 96.88 \\
\hline $\begin{array}{l}\text { HU after six months } \\
\text { post-operative }\end{array}$ & 329.38 & 215.38 & 346.78 & 345.77 & 456.67 & 345.68 \\
\hline $\begin{array}{l}\text { HU after nine months } \\
\text { post-operative }\end{array}$ & 588.27 & 636.86 & 578.98 & 765.23 & 897.79 & 768.89 \\
\hline
\end{tabular}




\section{DISCUSSION}

Two main techniques were reported by Summers for maxillary sinus augmentation; the crestal and lateral approaches. The most commonly used one is the lateral approach, which is indicated when the subantral bone height is $5 \mathrm{~mm}$ as was the case with patients included in this study ${ }^{[13,14]}$. Lateral sinus lift is reported to have several advantages. It provides direct vision of the sinus membrane, and it can be carried out with or without the use of a graft or filling material ${ }^{[15,22]}$. In lateral sinus lift, the buccal cortex can be either preserved or totally removed ${ }^{[23]}$. Whether to preserve the buccal wall of the window or not is controversial. The design of the window is a key factor for a successful sinus lift procedure. Traxler and colleagues recommended a small size window to ensure adequate endosseous arterial anastomosis ${ }^{[24]}$. However, we found nothing to support any negative effect of the increased window size on the healing process in our study.

Digital panoramic CT and cone beam computed tomography (CBCT) examinations were performed in this study preoperatively to assess the vertical dimension of bone in order to select proper implant length. The results of this study showed that the blood clot that forms underneath the maxillary sinus is capable of forming bone but the density of bone formed after augmentation of the lifted maxillary sinus with Nanobone was significantly higher than that formed after non augmented sinus lifting. During the first nine months post-operatively, the density of Nanobone graft placed under the elevated sinus membrane increased more rapid than that of the bone formed after nonaugmented sinus lifting. The group that have undergone non-grafted sinus lifting showed lower radiodensity in the first three months post-operatively in the post-operative radiographs because only blood clot was filling the defect, after the first three months, the group showed increase in the radiodensity because organization of the blood clot took place and bone formation was taking place. Several studies reported that penetration of the nasal or sinus cavities with titanium implants caused no complications during healing ${ }^{[25,26]}$. Branemark et al. ${ }^{[27]}$ explained that the reason for lack of side effects was believed to be the osseointegration of the implant itself, which means direct contact between the implant surface and the living bone tissue. This osseointegration creates a barrier to the migration of the microorganisms or the inflammatory cells along the implant. If the osseointegration didn't occur for some reason, but instead fibro-integration occurs, this would lead to migration of the inflammatory process. To summarize, bone grafting with Nanobone provides better density to the bone formed after sinus lifting and augmentation than non-augmented sinus lifting

\section{CONCLUSION}

There is significant increase in density of bone formed after augmented sinus lifting with Nanobone more than that of newly formed bone after non-augmented sinus lifting in the first nine months after the maxillary sinus lifting operation with simultaneous implants placement.

\section{CONFLICT OF INTEREST}

There are no conflicts of interest.

\section{REFERENCES}

1. Garg AK. Augmentation grafting of the maxillary sinus for placement of dental implants: Anatomy, physiology, and procedures. Implant dentistry 1999;8:36-46.

2. Misch CM. Ridge augmentation using mandibular ramus bone grafts for the placement of dental implants: Presentation of a technique. Practical periodontics and aesthetic dentistry : PPAD 1996;8:127-135; quiz 138.

3. Marx RE. Clinical application of bone biology to mandibular and maxillary reconstruction. Clinics in plastic surgery 1994;21:377-392.

4. Dalkyz M, Ozcan A, Yapar M, Gokay N, Yuncu M. Evaluation of the effects of different biomaterials on bone defects. Implant dentistry 2000;9:226-235.

5. Liu Q, Douglas T, Zamponi C, Becker ST, Sherry E, Sivananthan S, Warnke F, Wiltfang J, Warnke $\mathrm{PH}$. Comparison of in vitro biocompatibility of nanobone((r)) and biooss((r)) for human osteoblasts. Clinical oral implants research 2011;22:1259-1264.

6. Dietze $\mathrm{S}$, Bayerlein $\mathrm{T}$, Proff $\mathrm{P}$, Hoffmann A, Gedrange T. The ultrastructure and processing properties of straumann bone ceramic and nanobone. Folia morphologica 2006;65:63-65.

7. Abshagen K, Schrodi I, GerberT, Vollmar B. In vivo analysis of biocompatibility and vascularization of the synthetic bone grafting substitute nanobone. J Biomed Mater Res A 2009;91:557-566.

8. Tian XB, Sun L, Yang SH, Zhang YK, Hu RY, $\mathrm{Fu} \mathrm{DH}$. Osteogenic potential of the human bone morphogenetic protein 2 gene activated nanobone putty. Chinese medical journal 2008;121:745-751.

9. Belouka SM, Strietzel FP. Sinus floor elevation and augmentation using synthetic nanocrystalline and nanoporous hydroxyapatite bone substitute materials: Preliminary histologic results. Int J Oral Maxillofac Implants 2016;31:1281-1291. 
10. Boyne PJ. Analysis of performance of root-form endosseous implants placed in the maxillary sinus. J Long Term Eff Med Implants 1993;3:143-159.

11. Boyne PJ, Christiansen EL, Thompson JR. Advanced imaging of osseous maxillary clefts. RadiolClin North Am 1993;31:195-207.

12. Lundgren S, Andersson S, Gualini F, Sennerby L. Bone reformation with sinus membrane elevation: A new surgical technique for maxillary sinus floor augmentation. Clinical implant dentistry and related research 2004;6:165-173.

13. Summers RB. A new concept in maxillary implant surgery: The osteotome technique. Compendium (Newtown, Pa) 1994;15:152, 154-156, 158 passim; quiz 162.

14. Summers RB. The osteotome technique: Part 3-less invasive methods of elevating the sinus floor. Compendium (Newtown, Pa) 1994;15:698, 700, 702-694 passim; quiz 710

15. Palma VC, Magro-Filho O, de Oliveria JA, Lundgren S, Salata LA, Sennerby L. Bone reformation and implant integration following maxillary sinus membrane elevation: An experimental study in primates. Clinical implant dentistry and related research 2006;8:11-24.

16. Jodia K, Sadhwani BS, Parmar BS, Anchlia S, Sadhwani SB. Sinus elevation with an alloplastic material and simultaneous implant placement: A 1 stage procedure in severely atrophic maxillae. Journal of maxillofacial and oral surgery 2014;13:271-280.

17. Jensen J, Sindet-Pedersen S, Enemark $H$. Reconstruction of residual alveolar cleft defects with one-stage mandibular bone grafts and osseointegrated implants. Journal of oral and maxillofacial surgery : official journal of the American Association of Oral and Maxillofacial Surgeons 1998;56:460-466; discussion 467.

18. Jensen OT, Sennerby L. Histologic analysis of clinically retrieved titanium microimplants placed in conjunction with maxillary sinus floor augmentation. The International journal of oral and maxillofacial implants 1998;13:513-521.
19. Jensen OT, Shulman LB, Block MS, Iacono VJ. Report of the sinus consensus conference of 1996. The International journal of oral and maxillofacial implants 1998;13 Suppl:11-45.

20. Shulman J. A previously unreported surgical technique utilizing five different grafting materials to successfully achieve simultaneous alveolar regeneration and closure of a large oronasal defect. The Journal of oral implantology 1998;24:206-213.

21. Shulman LB. Avoiding and coping with surgically related implant problems. Dental implantology update 1998;9:29-30.

22. Shulman LB, Jensen OT. Sinus graft consensus conference. Introduction. The International journal of oral and maxillofacial implants 1998;13 Suppl:5-6.

23. Atef M, Hakam MM, ElFaramawey MI, AbouElFetouh A, Ekram M. Nongrafted sinus floor elevation with a space-maintaining titanium mesh: Caseseries study on four patients. Clin Implant Dent Relat Res 2014;16:893-903.

24. Traxler H, Windisch A, Geyerhofer U, Surd R, Solar P, Firbas W. Arterial blood supply of the maxillary sinus. Clinical anatomy (New York, NY) 1999;12:417-421.

25. Kim SH, Lee SJ, Cho IS, Kim SK, Kim TW. Rotational resistance of surface-treated mini-implants. The Angle orthodontist 2009;79:899-907.

26. Abrahamsson I, Zitzmann NU, Berglundh $\mathrm{T}$, Wennerberg A, Lindhe J. Bone and soft tissue integration to titanium implants with different surface topography: An experimental study in the dog. Int $\mathbf{J}$ Oral Maxillofac Implants 2001;16:323-332.

27. Branemark PI, Adell R, Albrektsson T, Lekholm $\mathrm{U}$, Lindstrom J, Rockler B. An experimental and clinical study of osseointegrated implants penetrating the nasal cavity and maxillary sinus. J Oral MaxillofacSurg 1984;42:497-505. 